\title{
Investigation on Length-Weight Relationship of Penaeus monodon (Fabricius, 1798) in Kakkaithevu Coastal Waters in the Northern Part of Sri Lanka
}

\author{
S. Piratheepa ${ }^{*}$, U. Edrisinghe $^{1}$ and K. Chitravadivelu ${ }^{2}$ \\ Postgraduate Institute of Agriculture \\ University of Peradeniya \\ Sri Lanka
}

\begin{abstract}
A detailed study on the length-weight relationship of Penaeus monodon (Fabricius, 1798) in Kakkaithevu coastal waters in the northern part of Sri Lanka was conducted from the commercial catches during November 2010 to September 2011. The overall weight of the $\underline{P}$. monodon individuals varied between $6.4 \mathrm{~g}-46.3 \mathrm{~g}$ and the lengths ranged from $96 \mathrm{~mm}$ to $189 \mathrm{~mm}$. The regression coefficient " $b$ " and constant " $a$ " tests were performed to compare the $b$ values of males and females from the hypothetical value of 3 . The calculated length-weight relationships obtained for male, female and pooled were $W=0.0054 L^{3.0748}, W=0.0062 L^{3.016}, W=0.0039 L^{3.2183}$, respectively. The " $b$ " value of male (3.0748) and female (3.016) did not differ significantly from the hypothetical value of 3 $(p>0.05)$. The values of both males and females were close to 3 , which indicated an approximate isometric growth pattern in $\underline{P}$. monodon. The values obtained for the mean weight by sex show that females were significantly $(p<0.05)$ heavier than the males. The information on length-weight relationship helps in selecting suitable species or varieties of faster growth rate for culture and assessment of the duration of the culture period for the attainment of marketable size of the $\underline{P}$. monodon.
\end{abstract}

Keywords: Coastal waters, isometric growth, length-weight relationship, Penaeus $\underline{\text { monodon }}$

\section{INTRODUCTION}

The penaeid shrimp fishery is one of most important fishery resources in Sri Lanka. Shrimps of genus Penaeus have a great demand in the export market. Penaeus monodon (Fabricius, 1798) is commonly referred to as the black tiger shrimp and is one of the seven species of penaeid shrimps recorded along the Kakkaithevu coastal waters, in the northern part of Sri Lanka (Piratheepa et al., 2012). It is a marine crustacean that is widely reared for human food. It has the fastest growth rate among the other penaeid species (Chitravadivelu, 1993). Length-weight relationships are useful for a wide number of studies, such as estimating growth rates, age structure and other aspect of shrimp population dynamics (Tsoumani et al., 2006). Therefore, the knowledge of length-weight relationship has a vital role in the fisheries science. It helps in establishing mathematical relationship between the two variables which enables conversion of one variable to other to describe growth in the wild (Mayavu et al., 2005).

\footnotetext{
1 Department of Animal Science, University of Peradeniya, Peradeniya, Sri Lanka

2 Centre for Development of Fisheries, University of Jaffna, Jaffna, Sri Lanka

* Corresponding author: theepa04@gmail.com
} 
The ratio of the length-weight relationship of shrimp is known to be useful index of the condition of shrimp. Variability in the length-weight relationship is as an indicator of conditions that can reflect fluctuation in the uptake and allocation of energy in marine fishes and crustaceans. These morphometric variations can be affected by many factors such as food, stress (overcrowding and diseases), or reproductive cycle. Length-weight relationship of penaeid shrimps differ among sexes, species, seasons and sites in both wild and cultured populations (Reza Nahavandi et al., 2010).

The study of length-weight relationship of the penaeids is not only important in understanding the biology of the species and its population dynamics but it is also important for the proper management of their resources (Christine, 1997; Saratha, 2009). However, virtually no information is available on the length-weight relationship of $P$. monodon from coastal waters around Jaffna peninsula. Therefore, the present study was undertaken on the length-weight relationship of $P$. monodon in Kakkaithevu coastal waters in the Northern part of Sri Lanka.

\section{MATERIALS AND METHODS}

\section{Description of the study area}

The fishing grounds around Jaffna district and the estuary are resourceful when compared to other parts of the country. Jaffna estuary is a shallow coastal water body located on the Northern Province of Sri Lanka with vital economic importance. It lies between approximate $79^{\circ} \mathrm{E} 52^{\prime}-80^{\circ} \mathrm{E} 38^{\prime}$ longitudes and $9^{\circ} \mathrm{N} 26^{\prime}-9^{\circ} \mathrm{N} \quad 46^{\prime}$ latitudes. It has an area about 412 $\mathrm{km}^{2}$ (Chitravadivelu \& Arudpragasam, 1983). Kakkaithivu Coastal area was selected for this study (Fig. 1). Shrimp species found in this area is significant and it is a major fish landing centre in Jaffna district.

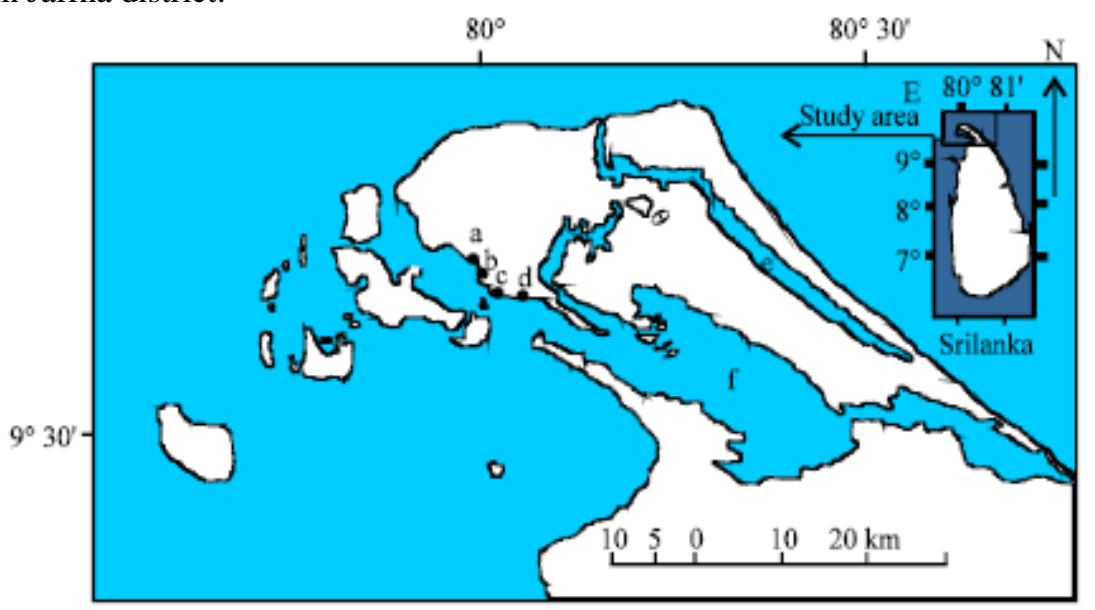

Fig. 1. Location of the Jaffna Estuary

(a) Kakkaithivu, (b) Navanthurai, (c) Kurunagar, (d) Pasaioor (e) Thondaimannar lagoon and (f) Jaffna estuary. 


\section{Data collection}

Random samples of shrimp were collected weekly from the commercial catches with specific gear sirahuvalai at Kakkaithivu Coastal waters in Jaffna district in the Northern Province for a period of one year from November, 2010 up to September, 2011. The samples were used to determine length- weight relationship of the shrimp P. monodon. For this reason, the species in each sample were identified and males and females were sorted by observing thelycum and petasma features (George \& Russell, 1994; Carpenter \& Niem, 1998). External morphology of P. monodon is shown in Fig 2.

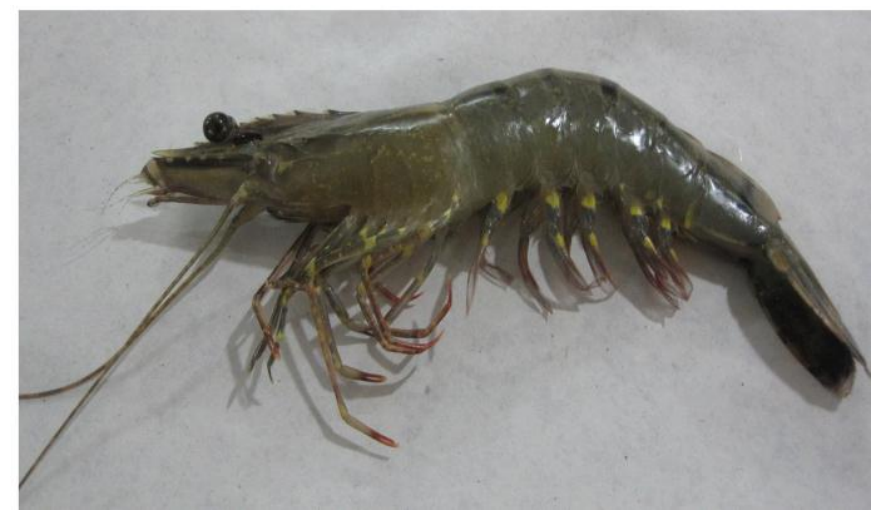

Fig. 2. External morphology of $P$. monodon.

\section{Morphometric measurements}

The total length (L) of each shrimp was measured from the tip of the rostrum to the end of the telson to the nearest $1 \mathrm{~mm}$ with a measuring board. Weight (W) was measured to the nearest $0.01 \mathrm{~g}$ by an electronic balance (Mettler Toledo, Model No. PG203-S, Switzerland) after wiping the moisture on the body of the shrimp.

\section{Regression analysis}

The length - weight relationship between total length and body weight was calculated by the Equation 1 proposed by Pauly (1983).

$$
\mathbf{W}=\mathbf{a L}^{\mathbf{b}}
$$

Where

$$
\begin{aligned}
& \text { W - total body weight }(\mathrm{mg}) \\
& \mathbf{L} \text { - total length of the body form }(\mathrm{cm}) \\
& \text { b - exponent } \\
& \text { a - constant }
\end{aligned}
$$

The length-weight relationships were estimated for males and females separately by using the logarithmic transformation of the above equation (Equation 2).

$$
\log _{10} W=\log _{10} a+b \log _{10} \mathrm{~L}
$$


Parameters " $a$ " and " $b$ " were estimated by linear regression on the logarithmic transformed equation. The degree of relation between the variables was computed by the coefficient of determination $\left(\mathrm{R}^{2}\right)$.

\section{Statistical analysis}

The "b" values were obtained for males and females separately. In order to test " $b$ " value against the isometric value of " 3 ", student's t-test was employed. Two sample t-tests were performed to compare the mean weight data of male and female to distinguish the differences between males and females.

\section{RESULTS AND DISCUSSION}

The total length of $P$. monodon ranged from $9.6-18.9 \mathrm{~cm}$ (mean $13.40 \mathrm{~cm}$ ) where males ranged from 9.6-16.4 cm (mean $13.36 \mathrm{~cm}$ ) and females ranged from 11.1-18.9 $\mathrm{cm}$ (mean $13.64 \mathrm{~cm})$.

The parabolic relationship between length and weight of males, females and pooled $P$. monodon is plotted in Figs. 3, 5 and 7, respectively. Similarly the logarithmic values of observed length and corresponding weights of males, females and pooled P. monodon are plotted in Figs. 4, 6 and 8, respectively. The regression plots of the transformed data indicated a linear relationship between the two variables.

For the length-weight relationship, the estimates of the regression parameters for males, females and pooled sexes obtained by regression analysis are shown in Table 1 . The equation of length-weight relationship and their logarithmic transformation are also given in Table 1.

Table 1. Relationship between length (L) and weight (W) in P. monodon collected from Kakkaithivu coastal waters, Jaffna.

\begin{tabular}{lllccc}
\hline Sex & $\begin{array}{l}\text { Length-weight } \\
\text { relationship }\end{array}$ & Logarithmic transformation & $\mathrm{r}$ & $\mathrm{b}$ & $\mathrm{a}$ \\
\hline Male & $\mathrm{W}=0.0054 \mathrm{~L}^{3.0748}$ & $\mathrm{Log} \mathrm{W}=-2.26+3.075 \log \mathrm{L}$ & 0.9786 & 3.0748 & 0.0054 \\
Female & $\mathrm{W}=0.0062 \mathrm{~L}^{3.016}$ & $\log \mathrm{W}=-2.20+3.016 \log \mathrm{L}$ & 0.9816 & 3.0160 & 0.0062 \\
Pooled & $\mathrm{W}=0.0039 \mathrm{~L}^{3.2183}$ & $\log \mathrm{W}=-2.40+3.218 \log \mathrm{L}$ & 0.9659 & 3.2183 & 0.0039 \\
\hline
\end{tabular}

The degree of association between the length and weight was computed from the linear regression analysis by the coefficient of determination $\left(\mathrm{R}^{2}\right)$. Correlation coefficient $(\mathrm{r})$ values were obtained by calculating the regression parameters (Table 1). Correlation coefficient (r) 0.9786 for males and 0.9816 for females were found to be significant $(\mathrm{p}<0.05)$ in both instances indicating good correlation between length and weight of $P$. monodon. 


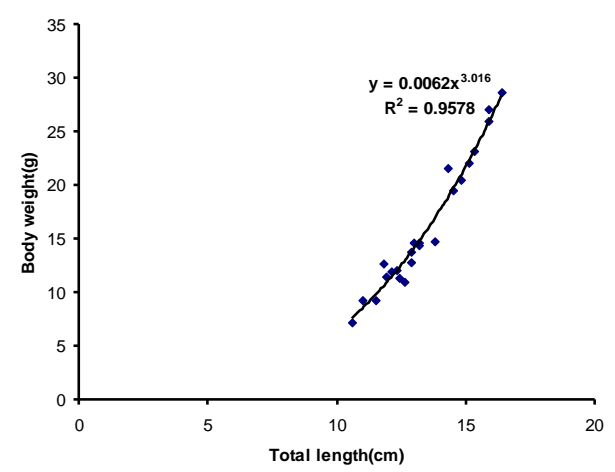

Fig. 3. Parabolic relationship between length $(\mathrm{mm})$ and weight (g) of male $P$. monodon.

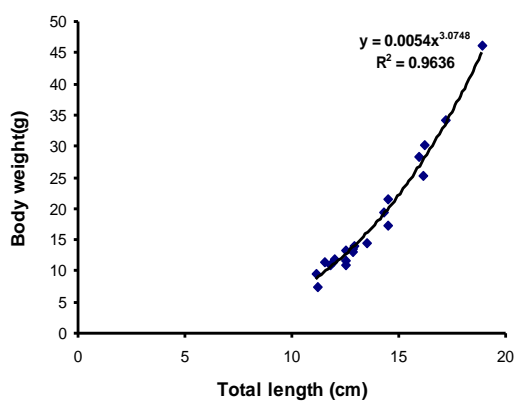

Fig. 5. Parabolic relationship between length $(\mathrm{mm})$ and weight (g) of female $P$. monodon.

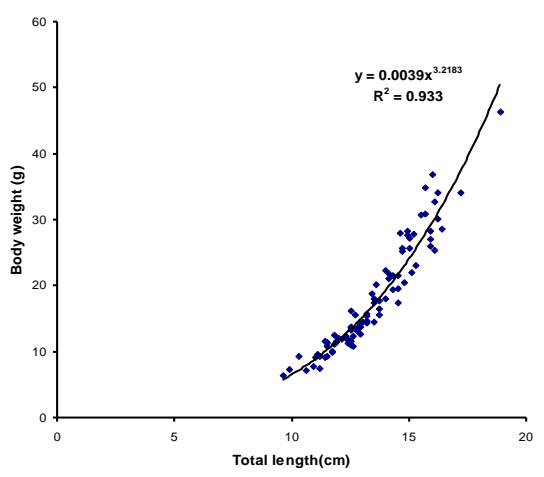

Fig. 7. Parabolic relationship between length $(\mathrm{mm})$ and weight (g) of pooled $P$. monodon.

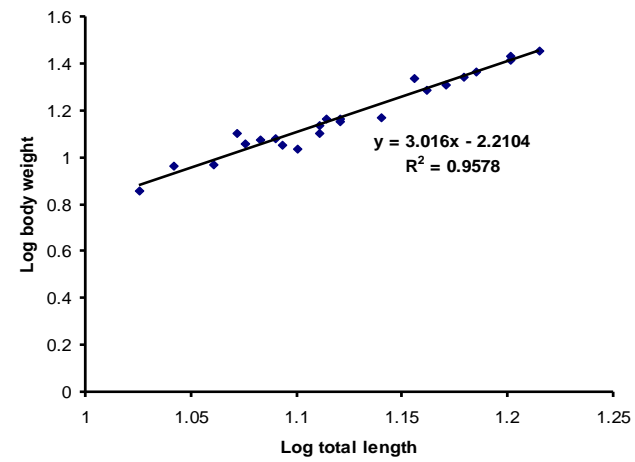

Fig. 4. Logarithmic relationship between length (mm) and weight $(g)$ in male $P$. monodon.

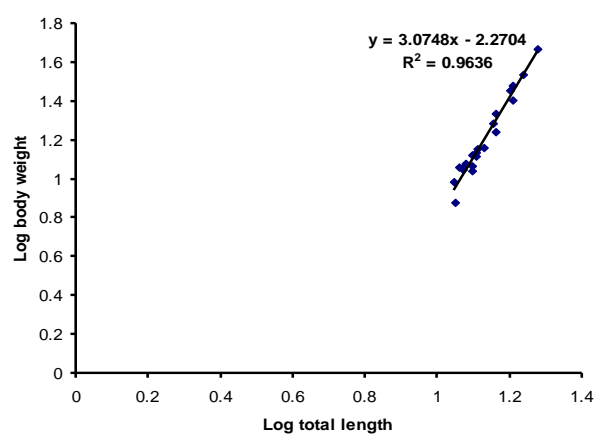

Fig. 6. Logarithmic relationship between length (mm) and weight (g) in female $P$. monodon.

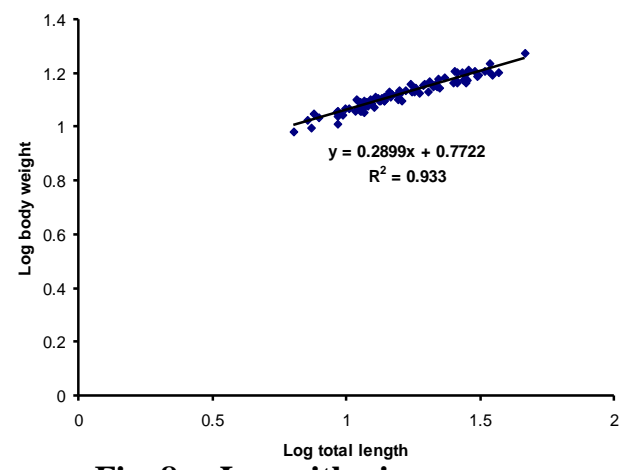

Fig. 8. Logarithmic relationship between length $(\mathrm{mm})$ and weight (g) of pooled $P$. monodon. 
King (1996) pointed out that the exponent (b) in the length-weight relationship of fishes is usually 3 . The ' $b$ ' value is very close to 3.0 but varies between 2.5 and 3.5 . If the ' $b$ ' value for fish is 3 , the fish grows isometrically; if it is greater than 3, the fish exhibits positive allometry and if it is lower than 3, the fish exhibits negative allometry (Tesch, 1968).

From the regression equation obtained in the present study, it is clear that the ' $b$ ' values traced for males (3.0748) and females (3.0160) were higher than 3 (Table 1). However, this species follows the cube law; its growth is proportionally three -dimensional. That is, with increasing age, rate of growth in terms of weight in this shrimp becomes faster than that of its length.

Table 2. Parameters obtained from two-sample t-test for mean weight of males and female $P$. monodon collected from Kakkaithivu Coastal waters, Jaffna.

\begin{tabular}{lll}
\hline & Length in Male $(\mathrm{mm})$ & $\begin{array}{l}\text { Weight of body in male } \\
(\mathrm{g})\end{array}$ \\
\hline Mean & 13.36521739 & 16.066 \\
Variance & 2.70055336 & 38.06282 \\
Observations & 98 & 98 \\
Pearson Correlation & 0.974159313 & \\
Hypothesized Mean Difference & 0 & \\
df & 97 & \\
t Stat & 2.825780446 & \\
P(T<=t) one-tail & 0.004920685 & \\
t Critical one-tail & 1.717144335 & \\
P(T<=t) two-tail & 0.009841371 & Weight of body in Female \\
t Critical two-tail & 2.073873058 & 17.97552 \\
& Length in Female & 95.87513 \\
\hline Mean & 13.64761905 & 153 \\
Variance & 4.596619048 & \\
Observations & 153 & \\
Pearson Correlation & 0.974101894 & \\
Hypothesized Mean Difference & 0 & \\
df & 152 & \\
t Stat & 2.569575919 & \\
P(T<=t) one-tail & 0.00914482 & \\
t Critical one-tail & 1.724718218 & \\
P(T<=t) two-tail & 0.01828964 & \\
t Critical two-tail & 2.085963441 & \\
\hline
\end{tabular}

The results of student's t-test to analyze the significance of variation in the estimates of ' $b$ ' for P. monodon from the expected value for the ideal fish or shrimp (3.0) are as follows:

Male $\quad:\left(3.0748-3.0 / 0.0424=0.2187\right.$; Not significant $\left(\right.$ Computed $\left.t_{a(2)} 0.05,97<1.984\right)$

Female : $(3.016-3.0) / 0.0371=0.034$; Not significant $\left(\right.$ Computed $\left.t_{a}(2) 0.05,152<1.962\right)$ 
Student t-test showed that the ' $b$ ' values obtained for male and female were not significantly different $(\mathrm{p}>0.05)$ from the hypothetical value of 3 indicating isometric growth for both male and female P. monodon in Kakkaithevu coastal waters in the Northern part of Sri Lanka.

The values obtained for the mean weights by sex compared by the two sample t-test are given in Table 2. Results show that females were significantly $(\mathrm{p}<0.05)$ heavier than males. The overall weight of the $P$. monodon individuals used for the study varied between $6.35 \mathrm{~g}$ $46.31 \mathrm{~g}$ and corresponding lengths ranged between $96 \mathrm{~mm}$ to $189 \mathrm{~mm}$.

\section{CONCLUSIONS}

Length-weight relationships for male, female and pooled $P$. monodon in Kakkaithevu coastal waters in the Northern part of Sri Lanka were $\mathrm{W}=0.0054 \mathrm{~L}^{3.0748}, \mathrm{~W}=0.0062 \mathrm{~L}^{3.016}, \mathrm{~W}=0.0039$ $\mathrm{L}^{3.2183}$, respectively. The present study on length-weight relationship of $P$. monodon showed that the $b$ values of male and female do not differ significantly from the hypothetical value of 3. The statistical analysis confirmed that males and females exhibit isometric growth. The values obtained for the mean weight by sex show that females were significantly $(\mathrm{p}<0.05)$ heavier than males. This information of length-weight relationship could be used in selecting suitable varieties having faster growth rate for culture and assessment of the duration of the culture period for the attainment of marketable size of $P$. monodon.

\section{REFERENCES}

Carpenter, K.E. and Niem, V.H. (1998). FAO species identification guide for fishery purposes. The living marine resources of the Western Central Pacific. Cephalopods, crustaceans, holothurians and sharks. Rome, FAO. Volume 2, pp 687-1396.

Chitravadivelu, K (1993). Shrimp Culture. University of Jaffna Publication. Mahatma printing works, Eralali, Jaffna, pp 10-20.

Chitravadivelu, K. and Arudpragasam, K.D. (1983). Studies on the prawn fishery in the Jaffna lagoon. Proceedings of Sri Lanka Association for Advancement of Science. 39 (1), 47

Christine, M., Saldanha and Chatterji, A. (1997). Length weight relationship of laboratory reared penaeid prawn Penaeus monodon (Fabricius) (Crustacea: Penaeidae). Indian Journal of Marine Science. 26, 389-391.

George, H.P. and Russell, B.C. (1994). FAO species identification field guide for fishery purposes. The marine fishery resources of Sri Lanka. FAO. Rome, Italy, pp19-37.

King, R.P. (1996). Length-weight relationships of Nigerian coastal water fishes. Fiesbyte, $19,53-58$.

Mayavu, P., Rajasegar, M. and Ajmalkhan, S. (2005). Length-weight relationship of looseshell affected Penaeus monodon (Fabricius, 1798) in grow -out system. Indian J. Fish. 52(2), 233-234

Pauly, D. (1983). Some simple methods for the assessment of tropical fish stocks. FAO Fish. Tech. Pap., 234: pp 52 
Piratheepa, S., Chitravadivelu, K. and Edrisinghe, U. (2012). Updates on the species of the shrimps in Kakkaithivu Coastal waters, Jaffna, Sri Lanka. Tropical Agricultural Research. 24(1), 82-90.

Reza Nahavandi, Nurul Amin, S.M., Md. Shater Zakarina and Mariana Nor Shamsudin (2010). Growth and length weight relationship of Penaeus monodon (Fabricius) cultured in artificial sea water. Research Journal of fisheries and Hydrobiology, 5(1), 52-55.

Saratha, P.T. (2009). On the fishery and some aspects of biology of Penaeus (Melicertus) canaliculatus (Oliver, 1811) landed at Puthiappa, Kozhikode, Southwest coast of India. J. Mar. Biol. Ass. India. 51(1),126-129.

Tech, F.W. (1968). Age and growth. In: Methods for assessment of fish production in freshwaters, Ricker, W.E. (Ed). Blackwell Scientific Publications, Oxford, UK, pp93-120 .

Tsoumani, M., Liasko, R., Moutsaki, P., Kagalou, I., and Leonardos, I. (2006). Lengthweight relationship of an invasive cyprinid fish (Carassius gibelio) from 12 Greek lakes in relation to their trophic states. Journal of Applied Ichthyology. 22, 281-284. 